\title{
MAIZE FOR SILAGE II. The effect of urea and acid as preservative treament on rumen fermentations and on feeding values of silages
}

\author{
Setälä, J. ${ }^{1}$, Seppälä, J.1ํ), Pirinen, S. ${ }^{1}$, Poutiainen, E. ${ }^{1}$ ) and Pulli, S. ${ }^{2}$ ) \\ 1) University of Helsinki, Department of Animal Husbandry, 00710 Helsinki 71 \\ ${ }^{2}$ ) University of Helsinki, Department of Plant Husbandry, 00710 Helsinki 71
}

\begin{abstract}
The rumen fermentations and N-balances of rumen fistulated sheep were studied on diets of silages treated with urea and acid preservative. The digestibilities and feeding values of the silages were also calculated. The experiment was performed according to $5 \times 5$ Latin-square design. The digestibilities were determined by total collection the collection period lasting seven days. The rumen samples were taken on the last two days during the collection periods before and 1.5, 3.0, 4.5 and 6.0 hours after feeding. Besides the silages the animals received mineral mixture and water ad libitum.

Urea or acid treatment had no effect $(\mathrm{P}>0.05)$ on the consumption of silage DM. The consumption ranged from 1.7 to $1.9 \mathrm{~kg} \mathrm{DM} / 100 \mathrm{~kg}$ liveweight.

Urea did not have a clear effect on the VFA production in the rumen. It tended, however, to decrease the proportions of $\mathrm{C}_{3}$ and $\mathrm{C}_{4}-\mathrm{C}_{5}$ acids in the rumen. Acid preservative decreased the production of VFA and the proportion of $\mathrm{C}_{3}$-acid $(\mathrm{P}<0.05)$ in the rumen. The proportion of $\mathrm{C}_{2}$-acid was higher respectively, $(\mathrm{P}<0.05)$. The rumen ammonia levels were extremely high, $60-80 \mathrm{mg} / 100 \mathrm{ml}$, after feeding with urea treated silages. This was possibly partly due to the relatively short (14 days) adaptation time before collection period.

The urea or acid preservative treatment gave no clear responses regarding the apparent digestibility values of the silages. The DCP values were highest $(\mathrm{P}<0.05)$ in the urea treated silages, but no differences $(\mathrm{P}>0.05)$ were found between the energy values, which varied between $0.12-0.14 \mathrm{f} . \mathrm{u}$. $/ \mathrm{kg}$ of silage.

There were no differences in the $\mathrm{N}$-balances of the animals on different diets. The balances were positive on all diets.
\end{abstract}

\section{Introduction}

When the whole maize plant is made for silage at a proper vegetation stage, the silage contains a lot of energy and is suitable especially for growing cattle (Utley et al. 1973, Lelong 1976). Because of the low content of crude protein, maize silage should be supplemented at least by a protein concentrate. Urea may also be used, because rumen $\mathrm{NH}_{3}$ liberated from urea degradation in the rumen could be efficiently utilized by rumen microbes owing to the abundance of sugars available (HUBER et al. 1967, FENNER et al. 1970). 
When silage is made from raw material in which the DM content is about 20 percent, the fermentation process is often stabilized with an addition of urea or acid preservatives. These substances could, however, cause some feeding problems in regard to the acidity of silages for instance (WILKINson et al. 1976).

To throw light on these questions the effects of urea and acid treatments on the palatability and feeding values of the silages were studied. Rumen fermentation studies with sheep were also performed.

\section{Materials and methods}

The silages, their chemical composition, ensiling and quality have been described earlier (SEtäLÄ et al. 1979 b). The experimental design is shown in Table 1.

Table 1. Experimental design, crops and their ensiling.

\begin{tabular}{lrrrrr}
\hline & \multicolumn{5}{c}{ Silages } \\
\cline { 2 - 6 } & A & B & C & D & E \\
\hline Fodder kg/tower silo ..................... & 1500 & 1500 & 1500 & 1500 & 1500 \\
Urea, $\%$ of wet weight ................. & 0.5 & 1.0 & 0.5 & - & - \\
Acid mixture, ${ }^{*} 1 / 1000 \mathrm{~kg}$ of fodder & - & 4.0 & 4.0 & 4.0 & - \\
\hline
\end{tabular}

* Viher-acid: $45 \%$ sulphuric acid, $20 \%$ formic acid, $10 \%$ formaldehyde.

The digestibilities and feeding values of the silages and the rumen fermentations were studied according to $\mathbf{5} \times \mathbf{5}$ Lation-square design with five Finnish Landrace rams (liveweight $55 \mathrm{~kg}$ ) fitted with rumen fistulas. Each period lasted 21 days including a collection period of seven days. The principle of total collection was used.

The animals were fed twice a day. Besides silages they had free access to mineral mixture and water all the time. The composition of the mineral mixture was as follows: $\mathrm{Ca} 13.0 \%, \mathrm{P} 9.1 \%, \mathrm{Mg} 5.0 \%, \mathrm{NaCl} 22.1 \%$, Ca:P 1.4: 1 .

The animals received silages ad libitum during the first ten days ( $=$ ad libitum period). During the transition period and collection period the amounts of silages given were restricted to 90 percent of the ad libitum feeding so there were no refusals left. The amounts of mineral mixture and water consumed were determined during each collection period.

The faeces and urines were weighed and sampled each day during the collection period. From the faeces $10 \%$ of the total amount per day was taken after thorough mixing for the analyses. The urine of each animal was stored through one day in a bucket under the metabolic cage. To prevent microbial action $30 \mathrm{ml}$ of $10 \mathrm{~N} \mathrm{H}_{2} \mathrm{SO}_{4}$ was added to the buckets. From the urines $5 \%$ of the total daily amout was taken for analyses. 
Silages for the experiment were taken from the silos twice a week and the doses for the experimental animals were weighed for $3-4$ days at a time, after which they were stored in plastic bags in a cool place until feeding. The samples for the analyses were taken at the same time.

Rumen samples were taken before feeding, and 1.5, 3.0, 4.5 and 6.0 hours after feeding during each of the last two days of the collection period. The samples were treated as described by SYRJÄLÄ (1972).

The composition of silages and faeces were analyzed according to standard methods. The nitrogen content of the urine samples was determined by the Kjeldahl method.

From the rumen samples the $\mathrm{pH}$ was measured with a Beckman meter Model H 2 GWB. Ammonia was determined according to the method of McCullough (1967) and the VFA determinations were made by the gas chromatographic method (HUIDA 1973).

The statistical analyses were made with a MONROE 1960 computor and its statistical programs.

\section{Results and discussion}

\section{The palatability of the silages}

In spite of the low $\mathrm{pH}$ values $(3.5-3.6)$ the animals consumed willingly the silages so that the energy requirements at the maintenance level according to Kellner and Becker (1966) could be met. The average amounts eaten for silages A, B, C, D and E were 1.93, 1.73, 1.84, 1.88 and $1.81 \mathrm{~kg} \mathrm{DM} / 100 \mathrm{~kg}$ liveweight, respectively. These values are much higher than those found earlier (SETÄLÄ et al. 1979 a) for corn silage.

Urea or acid treatment did not have any significant effect $(P>0.05)$ on silage DM consumption. A positive response with urea treatment can only be attained if the crude protein content of the silage remains below $9 \%$ in the silage DM after urea addition (ANDRIEU and DEMARQullly 1974).

\section{The effect of urea and acid preservative on rumen fermentation}

Total VFA production in the rumen has been highest (Fig. 1, Table 2) 1.5 hours after feeding, when silage with $0.5 \%$ of urea included was fed. The yield of VFA has been most stable on diets with B-silage included. Urea has increased the total VFA production in the rumen on maize silage diets with lambs (ScHAADT and JoHnson 1964), but no response has been obtained with cows (Huber et al. 1967) or calves (Thomas and Wilkinson 1975).

The use of acid preservative decreased VFA production in the rumen the production being lowest when $\mathrm{D}$-silage was fed. There was, however, a significant difference $(\mathrm{P}<0.05)$ only between the $\mathrm{A}$ - and $\mathrm{B}$-silages and the $\mathrm{D}$ silage $1.5-3.0$ and 4.5 hours after feeding, respectively (Table 2 ). It is possible. that the formaldehyde in the preservative decreased the fermentation in the rumen as found by VANBELlE et al. (1978). This has been noted also on grass silage diets with sheep, when preservatives containing formic acid or a mixture of formic acid and formaldehyde were compared (SYRJÄLÄ 1972). Because 
Table 2. The average total VFA and $\mathrm{NH}_{3}$ concentrations in the rumen (A-E, see Table 1).

\begin{tabular}{|c|c|c|c|c|c|c|c|c|c|}
\hline & \multirow{2}{*}{$\begin{array}{l}\text { Time after } \\
\text { feeding, } h\end{array}$} & \multicolumn{5}{|c|}{ Silage } & \multirow{2}{*}{$\mathrm{P}<0.05$} & \multirow{2}{*}{$\mathrm{P}<0.01$} & \\
\hline & & A & B & $\mathrm{C}$ & D & E & & & \\
\hline \multirow{5}{*}{$\begin{array}{l}\text { Total VFA, } \\
\text { mmol/100 ml } \\
\text { rumen fluid }\end{array}$} & before & 6.58 & 6.68 & 6.97 & 6.57 & 6.24 & NS & NS & \\
\hline & 1.5 & 10.78 & 9.56 & 9.93 & 8.55 & 9.91 & $A-D$ & - & \\
\hline & 3.0 & 9.73 & 9.46 & 9.02 & 7.86 & 8.76 & $A-D$ & - & \\
\hline & 4.5 & 8.60 & 9.16 & 8.05 & 7.57 & 7.99 & $B-D$ & - & \\
\hline & 6.0 & 7.95 & 8.42 & 811 & 7.32 & 7.65 & NS & NS & \\
\hline \multirow{5}{*}{$\begin{array}{l}\mathrm{NH}_{3}-\mathrm{N} \\
\mathrm{mg} / 100 \mathrm{ml} \\
\text { rumen fluid }\end{array}$} & before & 13.2 & 22.3 & 18.6 & 12.8 & 12.0 & $\mathrm{C}-\mathrm{E}$ & \multirow{5}{*}{$\begin{array}{l}\mathrm{B}-\mathrm{A}, \mathrm{D}, \mathrm{E} \\
\mathrm{B}-\mathrm{A}, \mathrm{D}, \mathrm{E} \\
\mathrm{B}-\mathrm{A}, \mathrm{D}, \mathrm{E} \\
\mathrm{B}-\mathrm{A}, \mathrm{D}, \mathrm{E} \\
\mathrm{C}-\mathrm{D}, \mathrm{E}\end{array}$} & \multirow{5}{*}{$\begin{array}{l}\text { A, C-D, E } \\
\text { A, C-D, E } \\
\text { A-D }\end{array}$} \\
\hline & 1.5 & 61.9 & 85.4 & 59.1 & 22.2 & 21.5 & - & & \\
\hline & 3.0 & 52.1 & 84.4 & 47.6 & 22.7 & 25.5 & - & & \\
\hline & 4.5 & 29.5 & 56.5 & 29.6 & 13.1 & 16.3 & - & & \\
\hline & 6.0 & 21.6 & 40.3 & 20.7 & 11.7 & 12.7 & $\mathrm{~B}-\mathrm{A}, \mathrm{C}, \mathrm{D}, \mathrm{E}$ & & \\
\hline
\end{tabular}

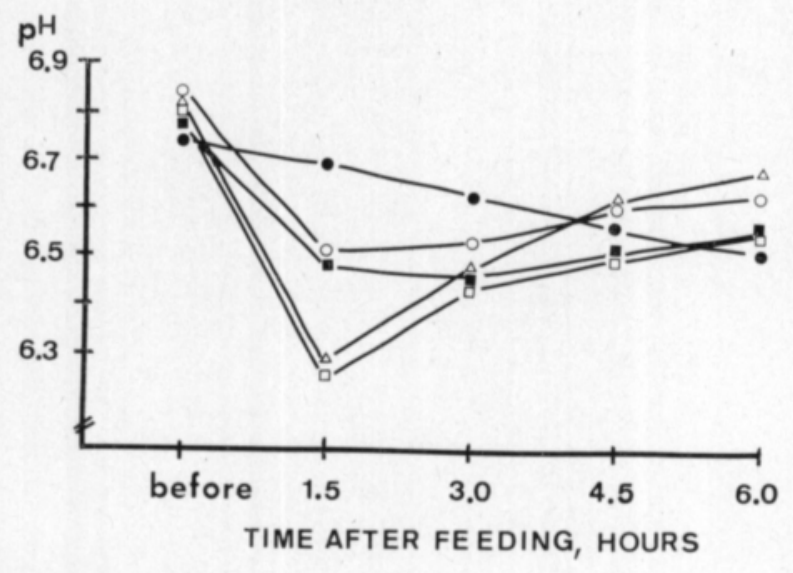

\section{VFAmmol/100ml}

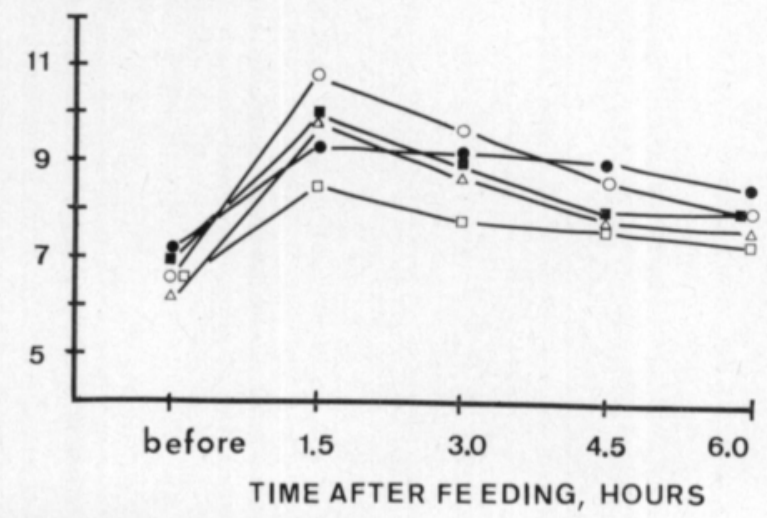

Figure 1. The rumen $\mathrm{pH}$ and total VFA before and 1.5-6.0 hours after feeding. o A, $\mathrm{B}, \mathbf{\mathrm { a }}$, $\bar{\square} \mathrm{D} \Delta \mathrm{E} \cdot(\mathrm{A}-\mathrm{E}$ see Table 1). 
of the high amount of readily available carbohydrates and the succulent nature of the maize silage, the proportion of propionic acid in the rumen VFA is usually quite high, the ratio of $\mathrm{C}_{2}: \mathrm{C}_{3}$ being 2.1-3.2 (BALwani et al. 1969, SchaAdt and Johnson 1969, Fenner et al. 1970).

Table 3. The molar proportions of VFA according to mole- $\%$ in the rumen fluid of sheep fed with different corn silages $(\mathrm{P}<0.05 \mathrm{a}-\mathrm{e})$. $\mathrm{A}-\mathrm{E}$ see Table 1.

\begin{tabular}{|c|c|c|c|c|c|c|}
\hline & Time after feeding, $\mathrm{h}$ & A & B & C & D & $\mathrm{E}$ \\
\hline \multirow[t]{5}{*}{ Acetic acid } & before feeding & 71 & 70 & 73 & 74 & 73 \\
\hline & 1.5 & $62^{a}$ & $70^{\mathrm{b}}$ & $67^{b}$ & $68^{b}$ & $63^{a}$ \\
\hline & 3.0 & $64^{a}$ & $71^{b}$ & $71^{b}$ & $69^{b}$ & $63^{\mathrm{a}}$ \\
\hline & 4.5 & $66^{a}$ & $73^{b}$ & $73^{b}$ & $71^{b}$ & $66^{\mathrm{a}}$ \\
\hline & 6.0 & $69^{a}$ & $74^{b}$ & $74^{b}$ & $72^{\text {be }}$ & $70^{\mathrm{ac}}$ \\
\hline \multirow[t]{5}{*}{ Propionic acid } & before feeding & 20 & 21 & 19 & 18 & 19 \\
\hline & 1.5 & $26^{\mathrm{a}}$ & $21^{\text {be }}$ & 22 be & $20^{\mathrm{be}}$ & $23^{b}$ \\
\hline & 3.0 & $24 \mathrm{a}$ & $20^{\mathrm{b}}$ & $18^{b}$ & $19^{b}$ & $22^{a}$ \\
\hline & 4.5 & $22^{a}$ & $18^{\mathrm{b}}$ & $17^{b}$ & $18^{\mathrm{b}}$ & $20^{\mathrm{a}}$ \\
\hline & 6.0 & $20^{\mathrm{a}}$ & $18^{\mathrm{ac}}$ & $17^{\text {be }}$ & $18^{\mathrm{ac}}$ & $18^{\mathrm{ac}}$ \\
\hline \multirow{5}{*}{$\begin{array}{l}\text { Butyric acid, isovaleric } \\
\text { and valeric acids }\end{array}$} & before feeding & 9 & 9 & 8 & 8 & 8 \\
\hline & 1.5 & $11^{\mathrm{ad}}$ & 9 be & $11^{\text {bed }}$ & $12^{\mathrm{bd}}$ & $14^{\mathrm{a}}$ \\
\hline & 3.0 & $12^{\mathrm{a}}$ & $9^{b}$ & $11^{\mathrm{a}}$ & $12^{\mathrm{a}}$ & $15^{e}$ \\
\hline & 4.5 & $12^{\mathrm{a}}$ & $9^{b}$ & $10^{\mathrm{a}}$ & $11^{\mathrm{a}}$ & $14^{\mathrm{a}}$ \\
\hline & 6.0 & 11 ae & $8^{b}$ & $9^{b d}$ & $10^{\text {bed }}$ & $12^{\mathrm{a}}$ \\
\hline
\end{tabular}

Compared to those results, the proportion of acetic acid in the rumen is high (Table 3). In their experiments the proportion of ears in silage DM must have been quite high which was not the case in the present trial. VERITE and JOURNET (1975) have shown that the proportion of grains can greatly influence the acetic (lower) and butyric (higher) acid production in the rumen. Possibly the chop length of the silage has also been different. In this trial the average chop length was $2-3 \mathrm{~cm}$ and according to ELY and SISK (1977) already it can cause the higher proportion of acetic acid in the ruminal VFA.

Urea has not affected the molar proportions of different VFA in the rumen. It appears that the proportion of $\mathrm{C}_{3}$ and $\mathrm{C}_{4}-\mathrm{C}_{5}$ acids have decreased. The proportion of $\mathrm{C}_{4}-\mathrm{C}_{5}$ acids is very low when silage treated with $1.0 \%$ of urea and Viher-acid has been fed.

The acid treatment of the silage increased the production of $\mathrm{C}_{2}-$ and decreased the production of $\mathrm{C}_{3}$-acid in the rumen. These changes were significant $(\mathrm{P}<0.05) \quad 1.5-4.5$ hours after feeding. It was also evident that the proportions of the $\mathrm{C}_{4}-\mathrm{C}_{5}$-acids had decreased.

Rumen ammonia concentrations after feeding have been extremely high (Table 2, Fig. 2). This was so especially when silage treated with $1 \%$ of urea and Viher-acid was fed. The effects of the different $\mathrm{NH}_{3}$-levels could also be seen in the $\mathrm{pH}$ values in the rumen (Fig. 1). 
The ammonia levels of diets that included urea are much above the desired levels suggested for microbial protein synthesis (SATTER and ROFFLER 1975) and for optimal feed digestion in the rumen on diets rich in carbohydrates (MEHREZ and Ørskov 1975). Levels are already too high when diets not including urea are considered. According to THOMAs and BROWN (1968, ref. HUBER et al. 1968) there is no response for instance in heifer gain from urea addition if the CP content in the silage DM is already 10 percent.

$\mathrm{mg} \mathrm{NH} / 100 \mathrm{ml}$

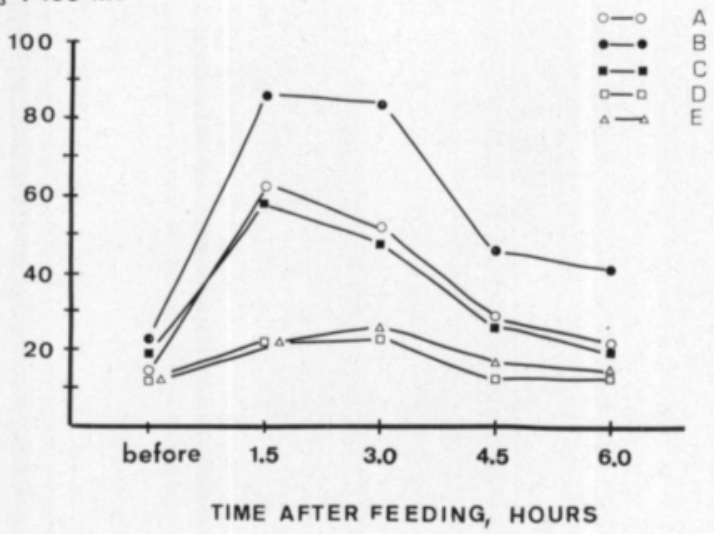

Figure 2. Rumen ammonia levels before and $1.5-6.0$ hours after feeding (A-E see Table 1).

These high ammonia levels could be accounted for by the relatively short adaptation period (14 days) for urea feeding when the feeding was changed according to the Latin-square design. According to Etrala et al. (1977), an adaptation period of 28 days was not long enough in the feeding of lactating cows. It should also be noted that urea was not degraded severely to ammonia during ensiling (SETÄLÄ et al. 1979 b).

When comparing the total VFA production in the rumen (Fig. 1) and the digestibility values (see later) it can be seen that the rumen microbes have not been able to utilize efficiently the nextra" ammonia liberated from the urea. The slight response of the Viher-acid treatment to the lower ammonia and fermentation levels could be explained by the formaldehyde of Viher-acid. SYRJÄLÄ (1972) e.g. has shown that the silage protein could be protected by the formaldehyde treatment.

\section{The digestibilities and feeding values of the silages}

The use of preservatives has not affected noticeably the apparent digestibility values (Table 4). The differences have only been significant in the digestibilities of crude fat $(\mathrm{P}<0.01)$ and $\mathrm{N}$-free extracts $(\mathrm{P}<0.05)$. It is somewhat difficult to explain these results, but a possible explanation for the better digestibility of the NFE-fraction in D-silage could lie in the higher concentration of sugars in silage DM (see SETÄLÄ et al. 1979 b). Generally the digestibility of the NFE-fraction has been lower in urea-treated silage, which has also been noted by Fornaroli and Perotti (1972) with sheep. 


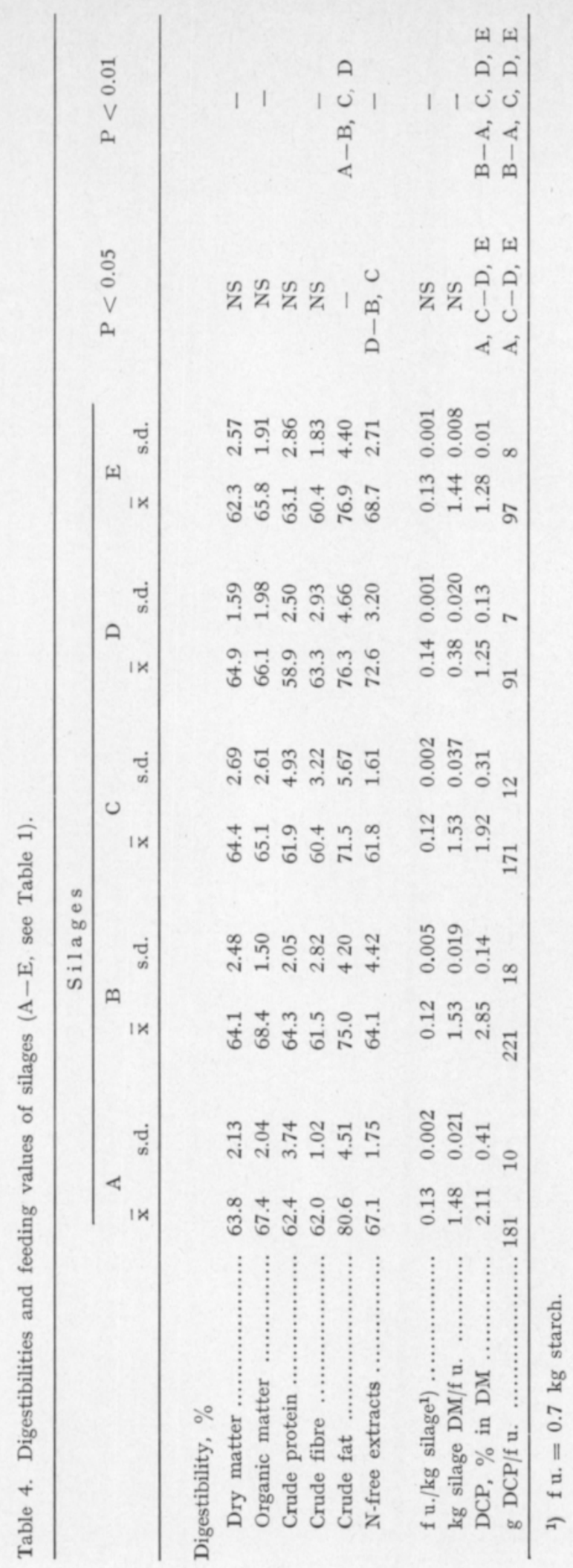


The use of urea as a preservative can increase the apparent digestibilities of crude protein and crude fat in maize silage (Polan et al. 1969 and KABUGA et al. 1973).

The use of acid preservative has tended to decrease the digestibility values in urea treated silages. This could be due to the lower fermentation in the rumen (see Fig. 1). When used with propionic acid, $0.5 \%$ of urea can improve the digestibility of silage DM, but there has been no response when urea has been used alone as a preservative (OtTERby and Murphy 1973). The use of propionic acid or formic acid alone has improved slightly the digestibility values (apart from crude fat) of maize silage (McGullough 1972, LEAver 1975).

The effect of urea on the feeding values of silage has been taken into account according to LAmpila (1968). There are no significant $(\mathrm{P}>0.05)$ differences in the energy values of the silages. Because of the low proportion of mature ears in the fodder mass ensiled, the energy values are quite low. However, when fed as a sole roughage ad libitum to a dairy cow, liveweight $500 \mathrm{~kg}$, the silages treated with $0.5 \%$ of urea would provide the energy and DCP requirements for maintenance and production of $10 \mathrm{~kg} \mathrm{FCM} /$ day.

The urea treated silages contained significantly $(\mathrm{P}<0.05)$ more digestible crude protein/f.u. These values are approximately the same as in grass silage made from $\mathrm{N}$-fertilized grass. Because of the possibility of high ammonia levels in the rumen and the danger of urea-rich layers of silage in tower silos (BöTtger 1969), it is not reasonable to use urea treatment of $1 \%$ in silage making.

\section{The nitrogen utilization of the animals}

The nitrogen balances have been positive in all diets (Table 5). The use of urea has not given a clear response in nitrogen retention $(\mathrm{P}>0.05)$, because the DCP requirements of the sheep could already be met by feeding maize silage without urea (KELLNER and BECKER 1966). The effects of the high $\mathrm{NH}_{3}$ levels in the rumen could also be seen from the $\mathrm{N}$ excretion in the urine of the animals fed with urea treated silages. The use of urea may improve the

Table 5. Nitrogen balances and $\mathrm{N}$ excretion in urine and faeces of the animals (A-E, see Table 1).

\begin{tabular}{|c|c|c|c|c|c|c|c|}
\hline & & \multicolumn{5}{|c|}{ Silages } & \multirow{2}{*}{$\mathrm{P}<0.01$} \\
\hline & & A & B & $\mathrm{C}$ & D & $\mathrm{E}$ & \\
\hline \multirow[t]{2}{*}{$\mathrm{N}$ intake, g/animal/d } & $\overline{\mathbf{x}}$ & 30.3 & 41.8 & 28.8 & 18.8 & 18.5 & - \\
\hline & s.d. & - & - & - & - & - & \\
\hline \multirow[t]{2}{*}{$\mathrm{N}$ in urine, $\mathrm{g} /$ animal/d } & $\overline{\mathbf{x}}$ & 20.9 & 31.9 & 19.4 & 9.7 & 9.7 & $\mathrm{~B}-\mathrm{A}, \mathrm{C}, \mathrm{D}, \mathrm{E}$, \\
\hline & s.d. & 1.297 & 3.868 & 1.146 & 1.717 & 1.061 & $\mathrm{~A}, \mathrm{C}-\mathrm{D}, \mathrm{E}$ \\
\hline \multirow[t]{2}{*}{$\mathrm{N}$ in faeces, $\mathrm{g} /$ animal/d } & $\overline{\mathbf{x}}$ & 7.1 & 8.9 & 8.1 & 7.0 & 6.5 & $\mathrm{~B}-\mathrm{A}, \mathrm{D}, \mathrm{E}$ \\
\hline & s.d. & 0.676 & 1.232 & 1.056 & 0.778 & 0.948 & \\
\hline \multirow{2}{*}{$\mathrm{N}$ balance, g/animal/d } & $\overline{\mathbf{x}}$ & 2.3 & 1.0 & 1.33 & 2.12 & 2.26 & NS \\
\hline & s.d. & 1.151 & 0.881 & 0.560 & 0.430 & 0.728 & \\
\hline
\end{tabular}


$\mathrm{N}$ retention with sheep on maize silage diet, if the $\mathrm{CP}$ content of the silage without urea is about $7 \%$ in DM (Fornaroli and PERotTi 1972).

The nitrogen excretion in faeces has been largest $(\mathrm{P}<0.01)$ on the B-silage diet. It is possible that large amounts of urea have reached the duodenum and have been degraded to ammonia which has been partly utilized by microbes in the caecum. It is possible that the proportion of endogenous nitrogen in faecal $\mathrm{N}$ could be larger with this diet compared to other diets.

\section{REFERENCES}

Andrieu, J. \& Demargullly, C. 1974. Feeding value of maize for forage. Influence of composition and fermentation characteristics on digestibility and voluntary intake of maize silage. Ann. de Zootechnie 23: 27-43.

Balwani, T. L., Johnson, R. R., McClure, K. E., Dehority, B. A. 1969. Evaluation of green chop and ensiled sorghums corn silage and perennial forages using digestion trials and VFA-production in sheep. J. Anim. Sci. 28:90-79.

Bötrger, C. 1969. Harnstoff zur Eiweissergänzung in Maissilage. Mitt. DLG 35: 1083-1086.

ELY, L. O. \& Sisk, L. R. 1977. The effect of fineness of cut of corn silage on digestibility and rumen fermentation. Amer. Dairy Sci. Assoc. Suppl. 1: 158.

Ettala, E., Mrkkonen, M., \& Lampila, M. 1977. Urea valkuaisen osittaisena korjaajana tuotantokauden keskivaiheessa. Kehittyvä Maatalous 34:16-23.

Fenner, H., Damon, R. A., Jr. \& Barnes, H. D. 1970. Effects of stepwise replacement of hay with corn silage on $\mathrm{pH}$, some organic metabolites and their changes in the rumen fluid of the bovine after feeding. J. Anim. Sci. 53: 1658-1577.

Fornaroli, D. \& Perottr, L. 1973. Digestibility and nitrogen balance trials on silage of whole maize plants made with urea. Nutr. Abstr. and Rev. 43:6227.

Huber, J. T., Sandy, R. A., Polan, C. E., Bryant, H. T. \& Blaser, R. E. 1967. Varying levels of urea for dairy cows fed corn silage as the only forage. J. Dairy Sci. 50: 1241 $-1247$.

- Polan, C. E. \& Hrllmann, D. 1968. Urea in high corn silage rations for dairy cattle. J. Anim. Sci. 27: 220-226.

HuIDA, L. 1973. Quantitative determination of volatile fatty acids from rumen sample and silage by gas-liquid chromatography. J. Scient. Agric. Soc. Finl. 45: 483-488.

Kabuga, J. D., Holter, J. B., Urban, W. E., Jr. \& Hayes, H. H. 1973. Utilization of nitrogensupplemented corn silage. J. Dairy Sci. 56: 1385 (Abstract).

Kellner, O., Becker, M. 1966. Grundzüge der Fütterungslehre. p. 252-260, 14. neuearb. Aufl. Paul Parey Verlag. Hamburg.

LampILA, M. 1968. Urea supplements in the rations of dairy cows. Ann. Agric. Fenn. 7: 46-58.

Leaver, J. D. 1975. The use of propionic acid as an additive for maize silage. J. Br. Grass. Soc. $30: 17-21$.

Lelong, C. 1976. For beef cattle, all forms of maize can be used. Anim. Feed Sci. and Tech. 1: $521-529$.

McCullough, H. 1967. The determination of ammonia in whole blood by a direct colorimetric method. Clin. Chim. Acta 17: 297-304.

McCullough, M. E. 1972. Effect of formic acid and dried steep liquor concentrate on digestibility and steer growth from corn silage. J. Anim. Sci. 34: 127-131.

Mehrez, A. Z. \& ØRskov, E. R. 1976. Rates of rumen fermentation in relation to ammonia concentration. Proc. Nutr. Soc. 35:40 A.

OtTerby, D. E., \& MURPhY, J. M. 1973. Nitrogen and acid additions to corn silage at ensiling. J. Dairy Sci. 56: 678 (Abstract).

Polan, C. E., Hall, J. W., Jr., Mrller, C. N. \& Sandy, R. A. 1969. Urea utilization by lactating cows when fed ensiled or in concentrates. J. Dairy Sci. 52: 557 (Abstract).

Satter, L. D. \& Roffler, R. E. 1975. Nitrogen requirement and utilization in dairy cattle. J. Dairy Sci. 58:1219-1237. 
SchaAdt, H., Jr. \& Johnson, R. R. 1969. VFA-production in the rumen of sheep fed limestone and urea treated corn silage. J. Anim. Sci. 29: 839-847.

Setälä, J., Seppälä, J., Pulli, S. \& Poutiainen, E. 1979 a. Preliminary studies on the conservation of whole sorghum and corn plant and sugar corn stover for silage. J. Scient. Agric. Soc. Finl. 51: 222-228.

- , Seppälä, J., Pulli, S \& Poutiainen, E. 1979 b. Maize for silage. I. Conservation of whole maize plant for silage with treatment of preservatives and urea before ensiling.

J. Scient. Agric. Soc. Finl. 51: 229-237.

SYRJÄL Ä, L. 1972. Effect of different sucrose, starch and cellulose supplements on the utilization of grass silage by ruminants. Ann. Agric. Fenn. 11: 199-276.

Tномаs, C. \& WrLkınson, J. M. 1975. The utilization of maize silage for intensive beef production 3. Nitrogen and acidity as factors affecting the nutritive value of ensiled maize. J. agric. Sci., Camb. 85: 255-261.

Utley, P. R., Lowrey, R. S. \& McCormick, W. C. 1973. Corn silage and corn silage plus small grain pasture for finishing steers. J. Anim. Sci. 36: 423-427.

VAnbelle, M., Arnould, R. \& Joassart, J. M. 1978. Effect of treatment of silage with formaldehyde on activity in the rumen, digestibility and retention of nitrogen in sheep. Publ. Lab. Biochim. Nutr. Fac. Sci. Agron. Louvain. 20. 16 p.

Verite, R. \& Journet, M. 1975. Feeding milking cow with maize silage. 2. Digestion in the rumen. Ann. de Zootechnie 24: 109-116.

Wilkinson, J. M., Huber, J. T. \& Henderson, H. E. 1976. Acidity and proteolysis as factors affecting the nutritive value of corn silage. J. Anim. Sci. 42: 208-218.

Ms received November 30, 1979.

\title{
SELOSTUS
}

\section{Maissi säilörehun raaka-aineena II. Säilöntöaineena käytetyn Viherhapon ja urean vaikutus pötsin käymistapahtumiin ja säilörehun rehuarvoon}

\author{
Setälä, J.1 ${ }^{1}$, Seppälä, J.1), Pirinen, S. ${ }^{1}$ ), Poutiainen, E. ${ }^{1}$ ), Pulli, S. ${ }^{2}$ ) \\ 1) Helsingin yliopiston kotieläintieteen laitos, $00710 \mathrm{Helsinki} 71$ \\ 2) Helsingin yliopiston kasvinviljelytieteen laitos, 00710 Helsinki 71
}

Tutkimuksen toisessa osassa pyrittiin selvittämään säilöntäaineena käytetyn urean ja Viherhapon vaikutusta pötsikäymiseen säilörehudieeteillä sekä vaikutusta maissisäilörehujen rehuarvoon. Lisäksi määritettiin eläinten typpitase eri ruokinnoilla. Koekaaviona oli $5 \times 5$ latinalainen neliö ja säilörehujen sulavuus määritettiin kokonaiskeruumenetelmällä keruukauden ollessa 7 päivää. Pötsinäytteet otettiin keruukauden kahtena viimeisenä päivänä ennen ja 1.5, 3.0, 4.5 ja 6.0 tuntia jälkeen ruokinnan. Koe-eläimet olivat pötsifistelöityjä pässejä, jotka säilörehujen lisäksi saivat kivennäisseosta ja vettä vapaasti.

Urea tai Viherhappo eivät vaikuttaneet säilörehujen maittavuuteen. Keskimäärin pässit söivät 1.7-1.9 kg säilörehun kuiva-ainetta 100 elopainokiloa kohti.

Käytettäessä Viherhappoa VFA-määrä pötsissä ja $\mathrm{C}_{3}$-happojen osuus mooliprosentteina kokonais-VFA:sta alenivat $(\mathrm{P}<0.05)$. Urea alensi $\mathrm{C}_{3}-\mathrm{ja}_{4}-\mathrm{C}_{5}$-happojen osuutta pötsinesteessä joskaan muutos ei ollut aina selvä 1.5-6.0 tuntia ruokinnan jälkeen. Ureaa sisältävillä ruokinnoilla pötsin $\mathrm{NH}_{3}$-taso oli hyvin korkea. Ilmeisesti 14 päivän maittavuus- ja siirtokausi ei ollut riittävä totutukseen urea-ruokinnalle, kun siirryttiin eri urea-ruokinnoille koekaavion mukaan.

Rehujen välillä ei ollut selviä eroja sulavuudessa. Raakarasvan sulavuus oli korkein $0.5 \%$ urealla käsitellyssä rehussa ja typettömien uuteaineiden sulavuus Viherhapolla säilötyssä rehussa. Säilörehujen ry-arvot vaihtelivat $0.12-0.14 \mathrm{ry} / \mathrm{kg}$. Urean lisäys kohotti säilörehujen srv-pitoisuuden $170-180 \mathrm{~g}$ srv/ry $(0.5 \%$ ureaa) ja $220 \mathrm{~g}$ srv/ry (1.0 \% ureaa).

Urea tai Viherhappo eivät vaikuttaneet eläinten typpitaseeseen. Säilörehujen srv-sisältō olisi riittänyt ilman ureaakin täyttämään lampaan srv-tarpeen ylläpitotasolla. 